\title{
Actants and Circonstants in the Semantic Situation “Congratulation" in the Chinese Literary Texts and Its Translations
}

\author{
Karine A. Kardash* \\ Siberian Federal University \\ 79 Svobodny, Krasnoyarsk, 660041, Russia
}

Received 20.09.2015, received in revised form 11.12.2015, accepted 17.02.2016

Our study refers to the research of the semantic situation "congratulation" in the communicative act in the Chinese language from the standpoint of translation. We will try to describe the semantic situation "congratulation" with the presented situation participants and compare the original text with two Russian translations. The study of the semantic situation "congratulation" is aimed at analysis of new aspects in the theory and practice of translation and intercultural communication.

Keywords: semantic situation, congratulation, literary text, anthropocentrism, translation, actant, circonstant, cultural worldview.

DOI: 10.17516/1997-1370-2016-9-3-637-645.

Research area: philology.

\section{Introduction}

There have been significant changes in linguistics and other humanities recently. The reason is that the scientific paradigm is moving from considering only the language as an independent semiotic system to understanding it as "an anthropological phenomenon" (Kubriakova). The linguistic research is refocusing within a new paradigm called the anthropocentric paradigm.

Anthropocentrism as a special method of research is characterized by the fact that the research objects are studied primarily in their role for a person, according to the purpose in his/herlife, according to their functions for the development of the human personality and its improvement. It is being implemented in two directions: 1) "the person is in the language", when he/she acts as an exponent of consciousness and the translator of cultures, and 2) "the language is in the person", that means the language and culture determine all things (Kubriakova). All these mindsets are related to the study of the following problems of communication and human language: the language and spirit of human activity; language, thinking and consciousness of a person; language and human physiology; language and culture; language and communication; language and values of a person.

The anthropocentric approach puts a person in the main place. The study calls the language the most important property, the way of living. All the texts created by people reflect a trend of

(C) Siberian Federal University. All rights reserved

* Corresponding author E-mail address: karikardash@mail.ru 
their thought and the ways of presenting thought processes by means of the language. Within this paradigm, such sciences as cognitive linguistics, cultural linguistics and others were formed (Kostomarov). The development of linguistics in this area of study is concerned with the increased interest of researchers to the problem of the relationship of human language and thinking.

\section{Theoretical framework}

Contemporary syntax is also focused on the semantic and pragmatic components of communicative expressions, capturing the interesting fields of study in semantics and pragmatics. The semantic language model is predetermined by structure consisting of both subjective and objective reality, forms and processes of thinking. It reflects the person's position in the world. The central concept constructing all aspects of the semantics of statements is the notion of the semantic type of a statement, which comprises the objective and subjective elements of meaning. The statement, no matter how elementary it may be, exists only if the information about the world and objective reality is connected with subjective information coming from the speaker at the moment of communication (Shmeleva). In this regard, anthropocentrism in linguistics is explained by researches as the change of the perspective studies, the formulation of a new object of study the semantic situation and its model. In the study of the structure of the syntax a key role is given to the semantic situation. The object of this study is situations represented in the literary text and the semantic situation model.

There is an axiom that such kind of research is within the frame of so called cultural linguistics. This science is developing at the intersection of the following disciplines - linguistics and cultural studies. The subject of the cultural linguistics study is the language as a cultural translation of the information and demonstration of the unique culture of the people, which is reflected and fixed in the language. The language does not exist outside the culture, that is, outside the socially inherited combination of practical skills and ideas that characterize the life of a person (Sapir, 1993, p. 192). The culture of any nationality has a specific national character, and its foundation is based on the national mentality. So the basis is the reflection and embodiment of the national mentality.

Cultural worldview is the result of the fact that in different cultures people perceive, feel and experience the world in their own way and thus they create a unique image of the world, called "picture of the world", or linguistic world view. Cultural worldview is a complex of rational knowledge and understanding of the values, standards, customs, mentality of the own ("our") culture and other ("their") cultures. The knowledge and understanding of the culture of every nation provides identity, so that it is possible to distinguish one culture from another. Iu.M. Lotman compares the concept of culture with the concept of "biosphere" by V.I. Vernadskii: "Culture is a special organization that generates information. The same way as the biosphere reworks lifeless state into living one with the help of solar energy" (Vernadskii), culture, based on the resources of the world, transforms the non-information into the information" (Lotman, 1992, p. 10). Culture is like a twosided organization that generates information. Alternatively, it can also be called an "intellectual subject" carrying out three tasks: "1) to store and transmit information (since it has communication and memory mechanisms); it has a languages and can form true messages; 2) to implement algorithmic operations on correct conversion of these messages; 3 ) to form new messages" (Ibid, p. 33). These three main functions of the culture are associated with semiotics. In order to describe 
the culture, Iu.M. Lotman took another concept the semiosphere - the semiotic universe, that is space like the biosphere, without which the semiosis (the generation of the meaning and the interpretation of the sign) can't exist (Ibid, p. 14).

According to M.A. Kulinich's theory, the key components of any culture are standards (the rules developed in the society determining proper or improper behavior in certain situations), values (general point of view includes what most people consider right, good and desirable for themselves), and symbols, the most important of which is the language (Kulinich, 2002, p. 12). There are values at the center of any national culture; they are "surrounded", in turn, by principles, and these are implemented in some standards and regulations (Prokhorov, 2006, p. 20). The language is the main way of transmitting the information. It is universal because it is used in all societies; it plays an important role in maintaining the hierarchic relationships between people.

\section{Discussion}

Standards, values, symbols have different forms of realization, for example, they can be realized in holidays. Holidays, as a part of the culture and cultural traditions are reflected in the language. Congratulation as the linguistic expression of the holiday is an elementary communicative action, which describes the extralinguistic reality and the communicative action itself. So the situation "congratulation" can be attributed to the speech etiquette standards and rituals. The situation "congratulation" is a speech situation, so the acquisition of the greeting etiquette is mastering the speech etiquette. That is why we place "congratulation" in the standards of speech etiquette. The semantic situation "congratulation" is included in a group of values, which can be characterized as expressing "politeness".
The literary text is the study source for analyzing the holidays and congratulations. The components of the cultural information are words, phrases, sentences, and other items or pieces of the text, and certain formal and substantial continuum of the whole literary text as well. The certain aesthetic content transfers the literary texts to the literary phenomenon, global and national cultural heritage (Razumovskaya, Tarasenko).

A group of factors affecting the literary texts' translation process is determined by the difference of cultures. "There is often a need for cultural adaptation, so called adaptation of the target language and culture to the translation of the fundamentally foreign language and foreign culture information" (Kazakova, 2006, p. 123). A.L. Semenov points out that "the quality of the translation is often defined by the depth of the translator's knowledge about adequacy, similarities and peculiarities of the text context. However, the context is the product of mixing of some of the concepts in different linguistic cultures" (Semenov, 2000, p. 32). A translator should avoid individual and collective stereotypes of the nation in translating a literary text. The culture is a subject of the translator's analysis and study; as a result the translator must be objective and open-minded to interpreting unfamiliar realities of another ("their") ethnic culture.

\section{Methods}

Our study is devoted to the comparative analysis of the semantic situation "congratulation" in the modern Chinese novel "Flowers in the Sea of Evil" by Zeng Bu (1905) and its translation into Russian language by V. Semanov, published in 1990.

We will try to describe the semantic situation "congratulation" with the presented situation participants. According to the basic types of arguments (hereinafter referred to as 
actants) of the situation "congratulation" such as agent, addressee, benefactive, instrumentative, causer, causation, object, objective, instrument, partitive, patient, resultative, and subject, we will be able to make a comparative analysis of the semantic situation "congratulation" in the source language - the Chinese language and the target language - Russian, and will present our version of the translation into Russian taking into consideration our research results.

This table demonstrates the semantic situation "congratulation": the situation is associated with the congratulation of the main character, whose name is Wen Qing with his promotion. This situation reflects the following functions of the semantic situation: the reason of the congratulation, the realization of the congratulation, the fact of the communicative act and the result of the congratulations. The performative verb “to congratulate" (恭喜) indicates a microsituation in the complex semantic situation "congratulation" and serves as the background of the semantic situation "congratulation". Our study refers to the research of the semantic situation "congratulation" in the communicative act.

Let us consider a situation of "congratulation" as a complex semantic situation, with all its components and participants. In the situation of "congratulation", as in any other activity, the figure of the Subject is the most significant, without it the realization of this process is impossible. There is no any particular term for the Subject in Russian so we can call it Agent, i.e. the author of the congratulations. "Agent is a producer of an action" (Zolotova, 1988, p. 430). Co-actors or co-agents are friends, comrades, colleagues, relatives, some people participating in the situation by chance. For example, 雯青 (Wen Qing), 夫人 (wife), 门房 (a crowd of beggars).

The second compulsive participant of the situation is the recipient of the congratulations.
"The addressee is a component defining a person or more seldom a thing to which the informative, donative or emotive action is addressed" (Zolotov, 1988, p. 430). Our example demonstrates the following addresses: 大人 (Your Honor), 你 (you), 小表嫂 (Cao’s wife), 老爷 (lord).

Let us pay attention to the marked phrases in the Chinese language as in the example: 大人升 官, 大人高发. The translation by V. Semanov is: “Поздравляем вашу милость с повышением! Блестящей вам карьеры!” It is worth noting that the Chinese original text does not have any verb of congratulation but the translation has the performative verb "congratulate". There is also a wish in the translation text but it is expressed implicitly: “Блестящей вам карьеры!” According to the rules of etiquette communication, congratulations must be accompanied by the gratitude, but we have noticed none of the greetings is followed with thankful words. The translation also demonstrates this fact. However, there is non-verbal thanks, the recipient responds to the greetings: - 从重 发 付》, 《接着 谢 恩 请; “щедро одарил пришедших, написал благодарственное письмо императору”.

Actant is the element of the eventful proposition corresponding to the actor or subject in the situation. Circonstant is the action circumstance. Let us consider the actants and the circonstants of the semantic situation in Table 3.

Together with the predicate the presented actants fill the semantic and syntactic valencies of the sentence and the text, constructing the structure of the semantic situation. The predicate is the performative verb "congratulate", but in the original text the predicate is omitted. Let us consider now a schematic semantic situation "congratulation" in the Chinese text as follows:

Agent 门房 + Benefactive 大人 + Causation 升官, 高 发.

Agent 雯青 + Resultative 1 一一从重发付 +2 Resultative 接着 谢恩请训 +3 Resultative 


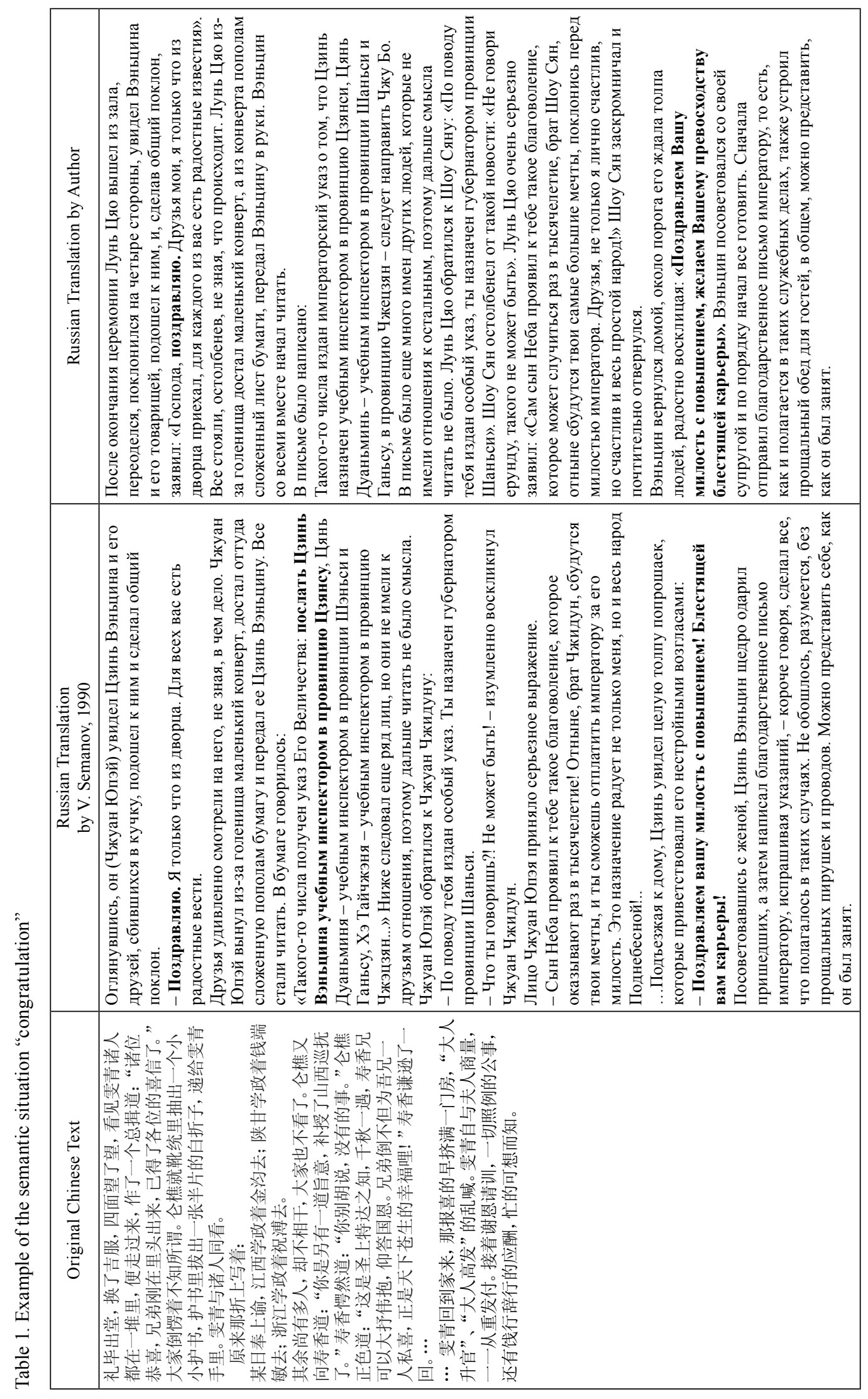


Table 2. Example of the semantic situation "congratulation"

\begin{tabular}{|c|c|c|}
\hline $\begin{array}{c}\text { Original Chinese } \\
\text { Text }\end{array}$ & Russian Translation by V. Semanov, 1990 & Russian Translation by Author \\
\hline $\begin{array}{l}\text { 雯青回到家来, 那 } \\
\text { 报喜的早挤满一门 } \\
\text { 房, “大人升官” } \\
\text { “大人高发” 的乱 } \\
\text { 喊。 } \\
\text { 雯青自与夫人商量, } \\
\text { 一一从重发付。接着 } \\
\text { 谢恩请训, 一切照 } \\
\text { 例的公事, 还有饯 } \\
\text { 行辞行的应酬, 忙得 } \\
\text { 可想而知。 }\end{array}$ & $\begin{array}{l}\text {... Подъезжая к дому, Цзинь увидел } \\
\text { целую толпу попрошаек, которые } \\
\text { приветствовали его нестройными } \\
\text { возгласами: } \\
\text { - Поздравляем вашу милость с } \\
\text { повышением! Блестящей вам } \\
\text { карьеры! } \\
\text { Посоветовавшись с женой, Цзинь } \\
\text { Вэньцин щедро одарил пришедших, } \\
\text { а затем написал благодарственное } \\
\text { письмо императору, испрашивая } \\
\text { указаний,- короче говоря, сделал все, } \\
\text { что полагалось в таких случаях. Не } \\
\text { обошлось, разумеется, без прощальных } \\
\text { пирушек и проводов. Можно } \\
\text { представить себе, как он был занят. }\end{array}$ & $\begin{array}{l}\text { Вэньцин вернулся домой, около порога } \\
\text { его ждала толпа людей, радостно } \\
\text { восклицая: «Поздравляем Вашу } \\
\text { милость с повышением, желаем } \\
\text { Вашему превосходству блестящей } \\
\text { карьеры». Вэньцин посоветовался со } \\
\text { своей супругой и по порядку начал } \\
\text { все готовить. Сначала отправил } \\
\text { благодарственное письмо императору, } \\
\text { как и полагается в таких служебных } \\
\text { делах, также устроил прощальный } \\
\text { обед для гостей, в общем, можно } \\
\text { представить, как он был занят. }\end{array}$ \\
\hline
\end{tabular}

Table 3. Actants and Circonstants

\begin{tabular}{|c|c|c|c|}
\hline Type of Actant & Chinese Language & $\begin{array}{l}\text { Russian Translation } \\
\text { by V. Semanov, } 1990\end{array}$ & Author's Translation \\
\hline \multirow{3}{*}{$\begin{array}{l}\text { AGENT } \\
\text { (SUBJECT) }\end{array}$} & 雯青 & Вэнь Цин & Вэньцин \\
\hline & 夫人 & Жена & Жена \\
\hline & 门房 & толпа попрошаек & толпа попрошаек \\
\hline $\begin{array}{l}\text { ADDRESSEE } \\
\text { (BENEFACTIVE) }\end{array}$ & 大人 & Вашу милость & $\begin{array}{l}\text { Вашу милость, Вашему } \\
\text { превосходству }\end{array}$ \\
\hline \multirow[t]{2}{*}{ CAUSATION } & 升官 & с повышением & $\begin{array}{l}\text { Поздравляем с } \\
\text { повышением }\end{array}$ \\
\hline & 高发 & Карьеры & $\begin{array}{l}\text { Желаем блестящей } \\
\text { карьеры }\end{array}$ \\
\hline \multirow[t]{5}{*}{ REZULTATIVE } & 一一从重发付 & одарил пришедших & $\begin{array}{l}\text { По порядку начал все } \\
\text { готовить }\end{array}$ \\
\hline & 接着谢恩请训 & $\begin{array}{l}\text { Написал } \\
\text { благодарственное } \\
\text { письмо императору }\end{array}$ & $\begin{array}{l}\text { отправил } \\
\text { благодарственное } \\
\text { письмо императору }\end{array}$ \\
\hline & 一切照例的公事 & $\begin{array}{l}\text { сделал все, что } \\
\text { полагалось в таких } \\
\text { случаях }\end{array}$ & $\begin{array}{l}\text { как и полагается в таких } \\
\text { служебных делах }\end{array}$ \\
\hline & 还有饯行辞行的应酬 & $\begin{array}{l}\text { Не обошлось без } \\
\text { прощальных пирушек и } \\
\text { проводов }\end{array}$ & $\begin{array}{l}\text { устроил прощальный } \\
\text { обед для гостей }\end{array}$ \\
\hline & 忙得可想而知 & $\begin{array}{l}\text { Можно представить } \\
\text { себе, как он был занят. }\end{array}$ & $\begin{array}{l}\text { Можно представить } \\
\text { себе, как он был занят. }\end{array}$ \\
\hline
\end{tabular}


还有 饯行 辞行 的 应酬, Resultative 4 一切 照 例 的 公事 + Resultative 5 忙得

The translated Russian text by the author Vladimir Semanov:

Agent (толпа попрошаек) + Predicate (поздравляем) + Benefactive (вашу милость) Causation +1 (с повышением)! Causation 2 (блестящей карьеры) + Benefactive (Вам)!

Agent 2(сженой) +Agent 1(ЦзиньВэньцин)

+ 1 Resultative (щедро одарил пришедших)

+ 2 Resultative (написал благодарственное письмо императору) + Resultative 3 (сделал все). Resultative 4 (прощальные пирушки и проводы). Resultative 5 (был занят).

\section{Our translation:}

Agent (Вэньцин) + Predicate 1 (вернулся) + Circonstant place 1 (домой), Circonstant place 2 (около порога) + Subject (толпа людей) + Predicate 2 (радостно восклицая): “Predicate 1 (Поздравляем) + Benefactive (Вашу милость) Causation 1 (с повышением), Predicate 2 (желаем)+Benefactive(Вашемупревосходству) + Causation (блестящей карьеры)".

Agent 1 (Вэньцин) + Predicate (посоветовался) Agent 2 (со своей супругой) + Predicate 2 (начал все готовить). Resultative 1 (отправил благодарственное письмо императору), + Resultative 2 (устроил прощальный обед для гостей), Resultative 3 (он был занят).

The actants and circonstants of the semantic situation "congratulation" will be named as: Agent - A, Benefactive - B, Causation - K, Resultative - R, Predicate - P, Circonstant (locative) - CL, Subject - S. Let us use these notation in our examples and schematically represent the original Chinese text, its translation into Russian and V. Semanov's translation.

\section{Conclusion}

Consequently, by analyzing the correlation of the original literary text and its translation into Russian, as well as the author's translation into Russian, the result is the following: the basic model of the semantic situation "congratulation" consists of a set of actants and circonstants. The Chinese original text demonstrates the greeting situation without the predicate "congratulate". But it is perceived as congratulation by native speakers. Therefore, the basic model of the semantic situation "congratulation" is supplemented by certain actants performing the function of congratulations, namely, the predicate "congratulate" in the Russian version.

In order to compare more than one Russian translation, we tried to present our translation into Russian considering all the peculiarities of the cultural standards and rituals of the foreign ("their") culture. Moreover, our translation expressed most accurately the context of the original meaning of the situation, and also saved the melody of the original text retaining the order of the words and closing the gap between "our" and "their" culture. With the extension of these studies the translations may become more precise, taking the reader closer to the Chinese culture, to the Chinese peculiarities of the Chinese language and the literary text itself.

Table 4. Three schemes of the semantic situation "congratulation"

\begin{tabular}{|l|l|l|}
\hline \multicolumn{1}{|c|}{ Original Chinese Text } & \multicolumn{1}{|c|}{$\begin{array}{c}\text { Russian Translation } \\
\text { by V. Semanov, 1990 }\end{array}$} & \multicolumn{1}{c|}{ Russian Translation by Author } \\
\hline $\begin{array}{l}\text { S+P+ CL+A+ "B+K1,B+K2" } \\
\text { A1+A2+P+R1+R2+R3+R4+R5 }\end{array}$ & $\begin{array}{l}\text { CL+S+P+A+P2: "P+B+K1! K2" } \\
\text { A2+A1+R1+R2+R3+R4+R5 }\end{array}$ & $\begin{array}{l}\text { A+P1+ CL1+ CL2+S+P2: } \\
\text { "P1+B+K1, P2+B+K2" } \\
\text { A1+P+A2+P2. } \\
\text { R1+ R2+R3+R4 }\end{array}$ \\
& & \\
\hline
\end{tabular}


It is worth noting that the correct perception, background, his/her ability to understand the life transmission and preservation of all the and the culture of the researched text. Such kind original national identity are difficult tasks in of syntactic and semantic studies in the aspect of solving practical and theoretical problems. The translation make different cultures closer to each successful translation depends on the translator's other and more respectful of each other.

\section{References}

Kazakova, T.A. (2006). Khudozhestvennyi perevod. Teoriia i praktika [Literary translation. Theory and Practice]. Saint-Petersburg, OOO “In"azizdat", 544 p.

Kostomarov, V.G. (2001). Starye mekhi $i$ molodoe vino. Iz nabliudenii nad russkim slovoupotrebleniem kontsa XX veka [The old wineskins and new wine. From observations of the Russian usage of the words at the end of the $20^{\text {th }}$ century]. Saint-Petersburg, Zlatoust Publ., $65 \mathrm{p}$.

Kubriakova, E.S. (1985). Padezhnaia grammatika [Case grammar], In Sovremennye zarubezhnye grammaticheskie teorii: Sbornik nauchno-analiticheskikh obzorov [Modern foreign grammatical theories: Coll. of scientific and analytical reviews], Moscow, INION, 37-54.

Kulinich, M.A. (2002). Vvedenie v lingvokul'turologiiu [Introduction to cultural linguistics]. Samara, SamGPU Publ., 190 p.

Lotman, Iu.M. (1992). Izbrannye stat'i v trekh tomakh. T1. Stat'i po semiotike i kul'turnoi topologii [Selected articles in three volumes. Vol.1. Articles on semiotics and cultural topology]. Tallinn, Aleksandra, 9-247.

Prokhorov, Iu., Sternin, I.A. (2006). Russkie: kommunikativnoe povedenie [Russians: Communicative Behavior]. Moscow, Nauka, 238 p.

Razumovskaya, V.A., Tarasenko, V.E. (2009). Situatsiia vinopitiia: semantika i perevod (na materiale romana M.A. Bulgakova "Master i Margarita" i ego iaponskogo perevoda) [Situation of wine drinking: semantics and translation (based on the novel by Mikhail Bulgakov "The Master and Margarita" and its Japanese translation)], In Iazyk, kommunikatsiia i sotsial'naia sreda [Language, communication and social environment], 7, 103-114.

Semenov, A.L. (2000). Osnovnye polozheniia obshchei teorii perevoda. [Main provisions of the general theory of translation]. Moscow, Muravei, $320 \mathrm{p}$.

Sapir, E. (1993). Izbrannye trudi po iazykoznaniiu i kul'turologii [Selected works on linguistics and culture studies]. Moscow, $459 \mathrm{p}$.

Shmeleva, T.V. (1994). Semanticheskii sintaksis: tekst lektsii [Semantic syntax: texts of lectures]. Krasnoyarsk, Krasnoyarsk State University, 48 p.

Vernadsky, V.I. (1967). Biosfera: Izbr. Trudy po biogeokhimii [Biosphere: selected works on biogeo-chenistry]. Moscow, Prosveshchenie, $367 \mathrm{p}$.

Zeng, B. (1990). Tsvety v more zla: roman [Flowers in the sea of evil: novel]. Moscow, Khudozh. Lit., $480 \mathrm{p}$.

曾朴《萑海花》(1905). Available at http://www.5156edu.com/html/10554/2.html (accessed 6 February 2016)

汉 俄 词典. 张 草 㧅. - 北京. $-2000-1250$ 页. 


\title{
Актанты и сирконстанты \\ в семантической ситуации «поздравление» \\ в китайском художественном тексте \\ в аспекте перевода
}

К.А. Кардаш

Сибирский федеральный университет Россия, 660041, Красноярск, пр. Свободный, 79

\begin{abstract}
Данное исследование посвящено изучению семантической ситуации «поздравление» в коммуникативном акте в китайском языке в аспекте перевода. Представим семантическую ситуацию «поздравление» со всеми участниками ситуации и сопоставим художественный текст оригинала на китайском языке с двумя переводами на русский язык. Изучение семантической ситуации «поздравление» позволит открыть новые аспекты перевода в теории и практике перевода, а также в межкультурной коммуникации.
\end{abstract}

Ключевые слова: семантическая ситуация, художественный текст, поздравление, антропоцентризм, перевод, актант, сирконстант, культурная картина мира.

Научная специальность: 10.00.00 - филологические науки. 